\title{
Trainee Teachers' Situational Motivation and Motivational Climate towards Physical Education Lessons during COVID-19 Pandemic
}

\author{
Ngien Siong Chin ${ }^{1}$, Boon Sian Teo ${ }^{1}$, Eng Hoe Wee ${ }^{2}$ \\ ${ }^{1}$ Institute of Teacher Education Batu Lintang Campus, Kuching, Sarawak, Malaysia \\ ${ }^{2}$ Tunku Abdul Rahman University College, Kuala Lumpur, Malaysia
}

\begin{abstract}
A B S T R A C T
This study examined the trainee teachers' situational motivation and motivational climate towards Physical Education lessons in primary schools during COVID-19 pandemic. The participants were 160 trainee teachers comprising of

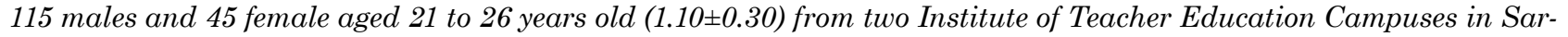
awak, Malaysia. The participants were administrated the Situational Motivation Scale (SIMS) and Teacher Initiated Motivational Climate in Physical Education Questionnaire (TIMCPEQ). Descriptive analysis, independent-samples t-test, one-way ANOVA, two-way ANOVA and correlations were utilized. Independent-samples t-test indicated that there were no significant differences for all variables in SIMS and TIMCPEQ on gender and age groups. The one-way ANOVA was used to compare the effect on teaching methods in SIMS and TIMCPEQ. There was a significant difference in teacherinitiated mastery orientation for the three teaching methods, $F(2,157)=3.31, p=0.04$. Post-hoc comparisons using the Tukey $H S D$ test revealed that the mean score for the online learning (3.87 \pm 0.78$)$ was significantly different than the mixed methods (4.22 \pm 0.55$)$. However, the face-to-face learning method (3.96 \pm 0.62$)$ did not significantly differ from the online learning and mixed methods. Furthermore, two-way ANOVA was used to examine the effect of gender and age groups in SIMS and TIMCPEQ which revealed no significant main effect of gender and age groups. Additionally, there was no statistically significant interaction between gender $\times$ age groups for all variables in SIMS and TIMCPEQ. The findings revealed statistically significant positive relationship between the variables in SIMS and TIMCPEQ ranging from very weak (0.24) to very strong (0.90). The findings revealed the necessity for positive motivational climate through adaptive educational resources, alternative teaching approaches and methods that would support and motivate the trainee teachers, educators and students in the teaching and learning of PE during this challenging time.
\end{abstract}

Key words: trainee teachers, motivation, climate, physical education

\section{Introduction}

The COVID-19 pandemic has resulted in an unparalleled and widespread impact on education globally. The closure of educational institutions such as schools and institution of higher learnings has affected educators and students which have eventually shaped the delivery of education dramatically across the globe. The world education systems have proactively adapted and innovated various inter-disciplinary distance learning approaches in order to continue with the educational process and system globally. Therefore, the educational institutions, scholars and educators have to change collectively en masse in terms of changing and transforming their instructional mode of delivery from curriculum to pedagogy, from teacher to learner, from learning to assessment and from location to time ${ }^{1}$. Indirectly, the pandemic has interrupted the traditional delivery of Physical Education to a digital approach in terms of teaching and learning as well assessment and evaluation methods as a modality during the pandemic lockdown. Moreover, the lockdown and isolation measures have impacted the people negatively in terms of their routine physical activity (PA) by reducing to diminishing levels of PA that impacted physical and mental health negatively. In the education settings, Physical Education (PE) educators and students have to resort to digital technologies to teach and learn online and expanding possibilities of new approaches to ensure that learning contin- 
ues during the pandemic. Generally, the educators resort to distance education and hybrid education which are conducted on strict protocols depending on the measures taken by the respective governments in their countries. Regardless of the models utilized, the educators have to utilize value-oriented and resources approach that facilitate and motivate healthy learning according to the competencies and abilities of the students within the PE settings. Similar to other academic lessons, Physical Education classes conducted online were re-structured and designed in their lessons as a high percentage of PE curriculum involving physical activities, movement and exercises which require utilizing sports equipment and facilities such as fields, tracks, courts and gyms. Online PE classes have to be based on innovation in terms of teaching strategies and pedagogies in order to ensure that the teaching and learning occurs with interaction and communication between the educators and students ${ }^{2,3}$.

Hence, motivation represents one of the fundamental factors in teaching and learning in a new and challenging environment in which both teachers and students need to achieve their teaching and learning outcomes respective$\mathrm{ly}^{4}$. The motivation of students towards active engagement in their classes as they transit from the traditional method to online classes is an important contributor in teaching and learning. Therefore, educators have to develop effective strategies and methodologies via virtual learning that can optimally motivate and induce varieties of motivational patterns among the students to engage in their PE lessons ${ }^{5}$. The transition from conventional to online learning has changed the educational landscapes of delivery of teaching and learning for both educators and students in which all parties would need to work together towards a better educational system ${ }^{6}$.

The situational motivation which is grounded within the self-determination theory reflects on one's engaging experience in an activity which can be applied in different situations and environment ${ }^{7}$. The situational motivation revolves on high levels of motivation (intrinsic motivation and identified regulation) and low levels of motivation (external regulation and amotivation) along the self-determination continuum ${ }^{8}$. Therefore, high motivation leads to higher attentiveness, concentration and effort and low levels of motivation showed poor concentration and boredom during the learning process respectively ${ }^{8,9}$. The types of motivation would also be influenced by the motivational climate which comprised of mastery-oriented climate and performance-oriented climate that can affect individuals' engagement and motivation in the class ${ }^{10}$. Mastery-oriented climate tends to lead to more self-determined motivation as compared to performance-oriented climate which would decrease self-determination motivation $^{11}$. With the divergence to online learning modalities, the schools' PE teachers would need to adapt their teaching methodologies and styles to facilitate a motivational climate for better engagement of the students towards learning PE in this COVID-19 pandemic. The PE teachers would be responsible to create a motivational climate that can accommodate the learners in their engagement in learning and behavior rising to the challenges faced during the COVID-19 ${ }^{12}$. This can foster the learning process efficiently which can motivate the students to sustain their learning process ${ }^{13}$.

There have been limited studies showing that females were more intrinsically and extrinsically motivated than males in Physical Education in Institutes of Higher Learning such as universities ${ }^{14}$, 15 . In addition, intrinsic and extrinsic motivation tend to have a positive association with task-and-performance motivational climate ${ }^{16}$. Moreover, Physical Education teachers did not show any significant differences in intrinsic motivation compared to extrinsic motivation in which the $20-29$ age group were significantly slightly higher than the older age groups which could be related to job satisfaction ${ }^{17}$.

Currently, with no studies examining the trainee teachers in situational motivation and motivational climate towards PE lessons in primary schools during COVID-19 pandemic, this study examined these two motivational elements of trainee teachers which were fundamental for educators to understand and contemplate their motivation in the PE setting during COVID-19 pandemic as well as contribute to the current PE educational literature.

\section{Material and Methods}

\section{Participants}

The participants consisted of 160 trainee teachers (115 males and 45 females) from two Institute of Teacher Education Campuses who were having their teaching practices in the primary schools in two divisions in Sarawak, Malaysia. They were aged $21-26$ years old. The questionnaires were administrated online through Google-form with voluntary consent of the participants and assurance of their confidentiality prior to the study. The Institutional Ethics Committee approved the ethics for the study.

\section{Measures}

The Situational Motivation Scale (SIMS) ${ }^{18}$ was utilized to measure individuals' situational motivation. The SIMS consists of four subscales across 14 items that measures behavioral regulations which are the intrinsic motivation (IM), identified regulation (IR), external regulation (ER) and amotivation (A). The items were rated on a 7-point Likert scale ranging from 1 (corresponds not at all) to 7 (corresponds exactly). The scale showed an acceptable internal consistency between 0.74 and $0.92^{19}$. The present alpha values showed acceptable to high reliability for intrinsic motivation (0.87), identified regulation (0.89), external regulation (0.68), amotivation (0.85) and overall SIMS (0.85).

The Teacher-initiated Motivational Climate in Physical Education Questionnaire (TIMCPEQ) ${ }^{20}$ measures the attitudes and behavioral perceptions regarding various 
aspects of engagement in PE. The 12-items TIMCPEQ comprised of two 6 -items subscales which measure teacher-initiated mastery orientation (TIMO) and teacher-initiated performance orientation (TIPO). The items were rated on a 5-point Likert scale ranging from 1 (strongly disagree) to 5 (strongly agree). The present questionnaire showed an internal consistency of 0.86 (TIMO), 0.85 (TIPO) and 0.85 (TIMCPEQ) respectively.

\section{Statistical analysis}

Descriptive statistics were computed through Statistical Package for Social Science (SPSS) version 26 in analyzing frequency, mean and standard deviation by gender, age groups, BMI and teaching methods. In addition, the independent $t$-test and two-way ANOVA were used to determine the differences between gender and age groups, and Pearson correlation coefficient to examine the relationship between the motivational variables.

\section{Results}

Table 1 showed the socio-demographic characteristics of the participants. A total of 160 participants were involved in the study, 115 (71.9\%) were males and 45 (28.1\%) were females. The age group categories showed that 144 (90.0\%) were $21-23$ years old and 16 (10.0\%) were $24-26$ years old. During COVID-19 period, the majority of the participants preferred to use face-to-face learning method with 75 (46.9\%), followed by online method with 47 (29.4\%) and mixed method with 38 (23.8\%). (Table 2)

Table 2 showed the independent-samples t-test of SIMS and TIMCPEQ based on gender. In SIMS, an independent-samples t-test was conducted to compare the intrinsic motivation, identified regulation, external regulation and amotivation for males and females. The findings revealed no significant difference in intrinsic motivation for males (5.44 \pm 1.04$)$ and females $(5.48 \pm 1.04)$; $\mathrm{t}(158)=-0.24$,

TABLE 1

SOCIO-DEMOGRAPHIC CHARACTERISTICS OF THE PARTICIPANTS

\begin{tabular}{lcc}
\hline Characteristics & Frequency (F) & Percentage (\%) \\
\hline Gender & & \\
Male & 115 & 71.9 \\
Female & 45 & 28.1 \\
Age Groups & & \\
$21-23$ & 144 & 90.0 \\
$24-26$ & 16 & 10.0 \\
Teaching methods & & \\
Online learning & 47 & 29.4 \\
$\quad$ Face-to-face learning & 75 & 46.9 \\
$\quad$ Mixed method & 38 & 23.8 \\
\hline
\end{tabular}

TABLE 2

INDEPENDENT-SAMPLES T-TEST OF SIMS AND TIMCPEQ BY GENDER

\begin{tabular}{lcccccc}
\hline \multirow{2}{*}{ Variables } & \multicolumn{2}{c}{ Male } & \multicolumn{2}{c}{ Female } & \multicolumn{2}{c}{ t-test } \\
SIMS & M & SD & M & SD & t & $\mathrm{p}$ \\
IM & & & & & & \\
IR & 5.44 & 1.04 & 5.48 & 1.04 & -0.24 & 0.81 \\
ER & 5.59 & 1.05 & 5.68 & 0.95 & -0.47 & 0.64 \\
AM & 4.87 & 1.04 & 5.12 & 0.96 & -1.42 & 0.16 \\
TIMCPEQ & 4.00 & 1.54 & 3.61 & 1.35 & 1.49 & 0.14 \\
TIMO & & & & & & \\
TIPO & 3.97 & 0.69 & 4.07 & 0.59 & -0.87 & 0.39 \\
\hline IM & 3.45 & 0.86 & 3.20 & 0.89 & 1.67 & 0.10 \\
\hline
\end{tabular}

$\mathrm{IM}=$ intrinsic motivation, $\mathrm{IR}=$ identified regulation, $\mathrm{ER}=$ external regulation, $\mathrm{AM}=$ amotivation, $\mathrm{TIMO}=$ teacher-initiated mastery orientation, TIPO = teacher-initiated performance orientation

$p=0.81$. Besides, there was no significant difference in identified regulation for males $(5.59 \pm 1.05)$ and females (5.68 \pm 0.95$)$; $\mathrm{t}(158)=-0.47, \mathrm{p}=0.64$. In addition, there was no significant difference in the external regulation for males (4.87 \pm 1.04$)$ and females $(5.12 \pm 0.96)$; $\mathrm{t}(158)=-1.42$, $\mathrm{p}=0.16$. Moreover, there was no significant difference in amotivation for males $(4.00 \pm 1.54)$ and females $(3.61 \pm 1.35)$; $\mathrm{t}(158)=1.49, \mathrm{p}=0.14$.

In TIMCPEQ, an independent-samples t-test was conducted to compare the teacher-initiated mastery orientation and teacher-initiated performance orientation scores for males and females. There was no significant difference in teacher-initiated mastery orientation for males (3.97 \pm 0.69$)$ and females (4.07 \pm 0.59$)$; $\mathrm{t}(158)=-0.87, \mathrm{p}=0.39$. In addition, there was no significant difference in teacher-initiated performance orientation for males $(3.45 \pm 0.86)$ and females $(3.20 \pm 0.89)$; $\mathrm{t}(158)=1.67, \mathrm{p}=0.10$. (Table 3)

TABLE 3

INDEPENDENT-SAMPLES T-TEST OF SIMS AND TIMCPEQ BY AGE GROUPS

\begin{tabular}{lcccccc}
\hline Variables & \multicolumn{2}{c}{$21-23$} & \multicolumn{2}{c}{$24-26$} & \multicolumn{2}{c}{ t-test } \\
\cline { 2 - 7 } & $\mathrm{M}$ & $\mathrm{SD}$ & $\mathrm{M}$ & $\mathrm{SD}$ & $\mathrm{t}$ & $\mathrm{p}$ \\
\hline SIMS & & & & & & \\
IM & 5.50 & 1.03 & 5.00 & 1.08 & 1.84 & 0.07 \\
IR & 5.66 & 1.02 & 5.23 & 1.00 & 1.59 & 0.12 \\
ER & 4.95 & 1.02 & 4.83 & 1.12 & 0.46 & 0.65 \\
AM & 3.94 & 1.44 & 3.42 & 1.89 & 1.33 & 0.30 \\
TIMCPEQ & & & & & & \\
TIMO & 4.01 & 0.63 & 3.86 & 0.96 & 0.59 & 0.57 \\
TIPO & 3.39 & 0.89 & 3.31 & 0.72 & 0.32 & 0.75 \\
\hline IM
\end{tabular}

$\mathrm{IM}=$ intrinsic motivation, $\mathrm{IR}=$ identified regulation, $\mathrm{ER}=$ external regulation, $\mathrm{AM}=$ amotivation, $\mathrm{TIMO}=$ teacher-initiated mastery orientation, TIPO = teacher-initiated performance orientation 
Table 3 showed the independent-samples t-test of SIMS and TIMCPEQ for age groups. In SIMS, an independent sample t-test was conducted to compare the intrinsic motivation, identified regulation, external regulation and amotivation scores for 21-23 years and 24-26 years. There was no significant difference in intrinsic motivation

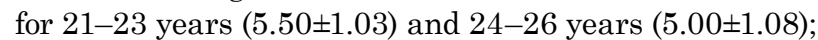
$\mathrm{t}(158)=1.84, \mathrm{p}=0.07$. There was no significant difference in identified regulation for $21-23$ years $(5.66 \pm 1.02)$ and $24-26$ years $(5.23 \pm 1.00)$; $\mathrm{t}(158)=1.59, \mathrm{p}=0.12$. Moreover, there was no significant difference in external regulation for $21-23$ years $(4.95 \pm 1.02)$ and $24-26$ years $(4.83 \pm 1.12)$; $\mathrm{t}(158)=0.46, \mathrm{p}=0.65$. Furthermore, there was no significant difference in amotivation for $21-23$ years (3.94 \pm 1.44$)$ and $24-26$ years $(3.42 \pm 1.89)$; $\mathrm{t}(16.99)=1.33, \mathrm{p}=0.30$.

In TIMCPEQ, an independent sample t-test was conducted to compare the teacher-initiated mastery orientation and teacher-initiated performance orientation scores for 21-23 years and 24-26 years. There was no significant difference in teacher-initiated mastery orientation for 21-23 years $(4.01 \pm 0.63)$ and $24-26$ years $(3.86 \pm 0.96)$; t $(16.46)=0.59, p=0.57$. In addition, there was no significant difference in teacher-initiated performance orientation for $21-23$ years $(3.39 \pm 0.89)$ and $24-26$ years $(3.31 \pm 0.72)$; $(158)=0.32, p=0.75$. (Table 4)

Table 4 showed the one-way ANOVA for SIMS and TIMCPEQ based on teaching methods. For SIMS, a oneway ANOVA was conducted to compare the effect of intrinsic motivation, identified regulation, external regulation and amotivation on online learning, face-to-face learning and mixed methods. There was no significant difference in intrinsic motivation for the three teaching methods, $\mathrm{F}(2,157)=0.22, \mathrm{p}=0.80$. In addition, there was no significant difference in identified regulation between teaching methods, $\mathrm{F}(2,157)=0.59, \mathrm{p}=0.55$. There was also

TABLE 4

ONE-WAY ANOVA OF SIMS AND TIMCPEQ BASED ON TEACHING METHODS

\begin{tabular}{|c|c|c|c|c|c|}
\hline $\mathrm{Va}$ & $\begin{array}{l}\text { Online } \\
\text { learning }\end{array}$ & $\begin{array}{c}\text { Face-to-face } \\
\text { learning }\end{array}$ & $\begin{array}{l}\text { Mixed } \\
\text { method }\end{array}$ & $\mathrm{F}$ & $\mathrm{p}$ \\
\hline & $\mathrm{SD}$ & $\mathrm{SD}$ & $\mathrm{SD}$ & & \\
\hline
\end{tabular}

\begin{tabular}{lrlllllll}
\hline SIMS & & & & & & & & \\
IM & 5.37 & 1.14 & 5.49 & 1.08 & 5.47 & 0.84 & 0.22 & 0.80 \\
IR & 5.49 & 1.12 & 5.64 & 1.01 & 5.72 & 0.93 & 0.59 & 0.55 \\
ER & 4.99 & 1.06 & 4.84 & 1.08 & 5.07 & 0.85 & 0.77 & 0.47 \\
AM & 3.84 & 1.51 & 3.79 & 1.41 & 4.15 & 1.64 & 0.77 & 0.46 \\
TIMCPEQ & & & & & & & \\
TIMO & 3.87 & 0.78 & 3.96 & 0.62 & 4.22 & 0.55 & 3.31 & $0.04^{*}$ \\
TIPO & 3.53 & 0.78 & 3.28 & 0.87 & 3.38 & 0.99 & 1.19 & 0.31 \\
\end{tabular}

$\mathrm{IM}=$ intrinsic motivation, $\mathrm{IR}=$ identified regulation, $\mathrm{ER}=$ external regulation, $\mathrm{AM}=$ amotivation, $\mathrm{TIMO}=$ teacher-initiated mastery orientation, TIPO = teacher-initiated performance orientation

$* \mathrm{p}<0.05$ no significant difference in external regulation between teaching methods, $\mathrm{F}(2,157)=0.77, \mathrm{p}=0.47$. Furthermore, there was no significant difference in amotivation between teaching methods, $\mathrm{F}(2,157)=0.77, \mathrm{p}=0.46$.

In TIMCPEQ, a one-way ANOVA was conducted to compare the effect of teacher-initiated mastery orientation on online learning, face-to-face learning and mixed method. There was statistically significant difference at the $\mathrm{p}<0.05$ level in teacher-initiated mastery orientation for the three teaching methods, $\mathrm{F}(2,157)=3.31, \mathrm{p}=0.04$. Posthoc comparisons using the Tukey HSD test revealed that the mean score for the online learning $(3.87 \pm 0.78)$ was significantly lower than the mixed methods (4.22 \pm 0.55$)$. However, the face-to-face learning method $(3.96 \pm 0.62)$ did not significantly differ from the online learning and mixed methods. However, there was no significant difference in teacher-initiated performance orientation scores between teaching methods, $\mathrm{F}(2,157)=1.19, \mathrm{p}=0.31$. (Table 5)

Table 5 showed the two-way ANOVA for gender and age groups on SIMS and TIMCPEQ. In SIMS, a two-way ANOVA was conducted to examine the effect of gender and age groups on intrinsic motivation, identified regulation, external regulation and amotivation. There were no significant main effect of gender, $\mathrm{F}(1,156)=0.73$, $\mathrm{p}=0.39$, $\eta_{\mathrm{p}}^{2}=0.005$, and age groups, $\mathrm{F}(1,156)=1.88, \mathrm{p}=0.17$, $\eta_{\mathrm{p}}=0.012$. There was no significant interaction between gender $\times$ age on intrinsic motivation, $\mathrm{F}(1,156)=0.75$, $\mathrm{p}=0.39, \eta_{\mathrm{p}}^{2}=0.005$. The main effect of gender, $\mathrm{F}(1,156)=0.01$, $\mathrm{p}=0.92, \eta_{\mathrm{p}}{ }^{2}<0.001$, and age groups, $\mathrm{F}(1,156)=2.47, \mathrm{p}=0.12$, $\eta_{\mathrm{p}}^{2}=0.016$ were not significantly different for identified regulation. There was also no significant interaction between gender $\times$ age on identified regulation, $\mathrm{F}(1,156)=0.07$, $\mathrm{p}=0.79, \eta_{\mathrm{p}}^{2}<0.001$. There was no significant main effect of gender, $\mathrm{F}(1,156)=0.42, \mathrm{p}=0.52, \eta_{\mathrm{p}}^{2}=0.003$, and age groups, $\mathrm{F}(1,156)=0.32, \mathrm{p}=0.57, \eta_{\mathrm{p}}^{2}=0.002$ on external regulation.

TABLE 5

MAIN-EFFECT OF GENDER VS AGE GROUPS FOR SIMS AND TIMCPEQ

\begin{tabular}{|c|c|c|c|c|c|c|c|}
\hline \multirow{2}{*}{ Variables } & \multicolumn{3}{|c|}{ Gender } & \multicolumn{3}{|c|}{ Age Groups } & $\begin{array}{l}\text { Gender vs } \\
\text { Age Groups }\end{array}$ \\
\hline & M & $\mathrm{F}$ & $\mathrm{p}$ & $21-23$ & $24-26$ & $\mathrm{p}$ & $\mathrm{p}$ \\
\hline
\end{tabular}

\section{SIMS}

$\begin{array}{lrllllll}\text { IM } & 5.17 & 5.43 & 0.39 & 5.50 & 5.10 & 0.17 & 0.39 \\ \text { IR } & 5.44 & 5.47 & 0.92 & 5.68 & 5.23 & 0.12 & 0.79 \\ \text { ER } & 4.84 & 5.03 & 0.52 & 5.01 & 4.85 & 0.57 & 0.77 \\ \text { AM } & 3.75 & 3.52 & 0.59 & 3.85 & 3.42 & 0.31 & 0.65 \\ \text { TIMCPEQ } & & & & & & \\ \text { TIMO } & 3.83 & 4.17 & 0.08 & 4.02 & 3.98 & 0.86 & 0.12 \\ \text { TIPO } & 3.41 & 3.21 & 0.44 & 3.33 & 3.29 & 0.89 & 0.76\end{array}$

$\overline{\mathrm{IM}}=$ intrinsic motivation, $\mathrm{IR}=$ identified regulation, $\mathrm{ER}=$ external regulation, $\mathrm{AM}=$ amotivation, $\mathrm{TIMO}=$ teacher-initiated mastery orientation, TIPO = teacher-initiated performance orientation 
There was no significant interaction between gender $\times$ age on external regulation, $\mathrm{F}(1,156)=0.09, \mathrm{p}=0.77, \eta_{\mathrm{p}}{ }^{2}=0.001$. The main effect of gender, $\mathrm{F}(1,156)=0.29, \mathrm{p}=0.59$, $\eta_{p}^{2}=0.002$ was significantly different on amotivation, but the main effect of age groups, $\mathrm{F}(1,156)=1.04, \mathrm{p}=0.31$, $\eta_{\mathrm{p}}^{2}=0.007$ was not significant. There was no significant interaction between gender $\times$ age on amotivation, $\mathrm{F}(1,156)=0.21, \mathrm{p}=0.65, \eta_{\mathrm{p}}^{2}=0.001$.

In TIMCPEQ, a two-way ANOVA was conducted to examine the effect of gender and age groups on teacher-initiated mastery orientation and teacher-initiated performance orientation. There was no significant main effect of gender, $\mathrm{F}(1,156)=3.17, \mathrm{p}=0.08, \eta_{\mathrm{p}}^{2}=0.020$, and age, $\mathrm{F}(1,156)=0.03$, $\mathrm{p}=0.86, \eta_{\mathrm{p}}^{2}<0.001$ on teacher-initiated mastery orientation. There was not significant interaction between gender $\times$ age on teacher-initiated mastery orientation, $\mathrm{F}(1,156)=2.45$, $\mathrm{p}=0.12, \eta_{\mathrm{p}}^{2}=0.015$. Additionally, a two-way ANOVA was conducted to examine the effect of gender and age groups on teacher-initiated performance orientation. The main effects of gender, $\mathrm{F}(1,156)=0.60, \mathrm{p}=0.44, \eta_{\mathrm{p}}^{2}=0.004$, and age, $\mathrm{F}(1,156)=0.02, \mathrm{p}=0.89, \eta_{\mathrm{p}}{ }^{2}<0.001$ were no significant. There was no significant interaction between gender $\times$ age on teacher-initiated performance orientation, $\mathrm{F}(1,156)=0.10$, $\mathrm{p}=0.76, \eta_{\mathrm{p}}^{2}=0.001$. (Table 6)

Table 6 showed the relationship between intrinsic motivation, identified regulation, external regulation, amotivation (SIMS), teacher-initiated mastery orientation and teacher-initiated performance orientation (TIMCPEQ). Intrinsic motivation was highly correlated with identified regulation $(\mathrm{r}=0.90)$ while moderately correlated with teacher-initiated mastery orientation $(r=0.66)$. Intrinsic motivation was moderately correlated with external regulation $(\mathrm{r}=0.47)$ and did not significantly correlate with amotivation $(r=-0.03)$, and weakly correlated with teacher-initiated performance orientation $(r=0.33)$. Besides, identified regulation was moderately correlated with external regulation $(r=0.51)$ and teacher-initiated mastery orientation $(\mathrm{r}=0.67)$, but weakly correlated with amotivation $(r=-0.12)$ and teacher-initiated performance orienta-

TABLE 6

CORRELATION BETWEEN VARIABLES OF SIMS AND TIMCPEQ

\begin{tabular}{lcccccc}
\hline Variables & IM & IR & ER & AM & TIMO & TIPO \\
\hline IM & - & $0.90^{* *}$ & $0.47^{* *}$ & -0.03 & $0.66^{* *}$ & $0.33^{* *}$ \\
IR & & - & $0.51^{* *}$ & -0.12 & $0.67^{* *}$ & $0.24^{* *}$ \\
ER & & & - & $0.42^{* *}$ & $0.44^{* *}$ & $0.41^{* *}$ \\
AM & & & & - & 0.07 & $0.52^{* *}$ \\
TIMO & & & & & - & $0.35^{* *}$
\end{tabular}

TIPO

$\mathrm{IM}=$ intrinsic motivation, $\mathrm{IR}=$ identified regulation, $\mathrm{ER}=$ external regulation, $\mathrm{AM}=$ amotivation, $\mathrm{TIMO}=$ teacher-initiated mastery orientation, TIPO = teacher-initiated performance orientation

**. Correlation is significant at the 0.01 level (2-tailed) tion $(r=0.24)$. Furthermore, external regulation was moderately correlated with amotivation $(r=0.42)$, teacher-initiated mastery orientation $(\mathrm{r}=0.44)$ and teacher-initiated performance orientation $(r=0.41)$. Moreover, amotivation did not significantly correlate with teacher-initiated mastery orientation $(r=0.07)$ but significantly moderately correlated with teacher-initiated performance orientation $(r=0.52)$. Lastly, teacher-initiated mastery orientation was weakly correlated with teacher-initiated performance orientation $(\mathrm{r}=0.35)$.

\section{Discussion}

The study aimed to examine the situational motivation and motivational climate among trainee teachers towards Physical Education lessons conducted during COVID-19 pandemic. The findings revealed surprising non-significant differences in terms of gender and age groups for situational motivation and motivational climate variables. These could be due to equal instructional approaches which were interactional and engaging and were provided for both genders during PE classes. However, females were slightly more intrinsically and extrinsically motivated simultaneously as compared to the males, which showed that females were more engaged with learning and mastery of the content and skills taught in PE classes. This finding was supported by similar studies which revealed that females were intrinsically and extrinsically motivated ascribing their motivation towards $\mathrm{PE}^{14,15}$. The females may have received more support and guidance and tend to be more self-regulated in their learning process from their mentor teachers during the teaching practices. Similar recommendation of provision for equal learning opportunities, content and resources can reduce gender stereotyping among teachers which can facilitate females' motivation towards $\mathrm{PE}^{21}$.

The non-significant differences between age groups revealed a supportive and motivating climate that encourage the learning process in PE lessons. The teacher-initiated mastery orientation created by the teachers in terms of encouragement, different and enjoyable activities, performance-based evaluations and feedback as well as fostered relatedness among the teachers and students would increase their level of motivation. The significant difference in teacher-initiated mastery orientation for three teaching methods showed that mixed methods comprising of face-to-face and online learning were the most preferred methods of learning. The positive relationship between intrinsic motivation and teacher-initiated mastery orientation showed the teachers were providing supportive autonomy and relatedness behaviors which create a more harmonious and cooperative relationship between teachers and students that enabled a more self-determination motivation. In addition, the emphasis on progressive self-reference, challenging effort and purpose of learning $\mathrm{PE}$ had motivated the students more intrinsically rather than extrinsically in PE lessons. The limitation of the study is that the findings may not be generalized due to 
small sample size and two Institute of Teacher Education campuses in Malaysia. Nevertheless, the study is able to provide a better understanding of the motivational variables underlying learning PE in terms of its relevancy during the COVID-19 pandemic uncertainty.

Future studies should look into the locality in terms of the rural areas whereby the schools are deprived of high internet connectivity and data access which are necessities, as well as lack of equipment and supplies which were required for PE lessons. In addition, the majority of the rural students which were from the lower socioeconomic backgrounds might not have access to computers for their online lessons or hybrid forms of learning in which the educators would need to utilize other forms of adaptive platforms to teach rural students.

The findings revealed the necessity for the education institutions and schools to address the challenges faced by both teachers and trainee teachers in supporting and de-

\section{R E F E R E N C E S}

1. ZHAO Y, WATTERSTON J, J Educ Change, 22 (2021) 3. doi: 10.1007/s10833-021-09417-3. - 2. BACKMAN E, BARKER DM, Phy Educ Sport Pedagogy, 25 (2020) 451. - 3. VAREA V, GONZÁLEZ-CALVO G, Sport Educ Soc, (2020) 1. - 4. SMITH M, LOEWEN S, The TESOL Encyclopedia of English Language Teaching, (2018) 1. - 5. AMES C, ARCHER J, J Educ Psychol, 80/3 (1988) 260. doi:10.1037/00220663.80.3.260. - 6. KHALIL R, MANSOUR AE, FADDA WA, ALMISNID K, ALDAMEGH M, AL-NAFEESAH A. ALKHALIFAH A, ALWUTAYD O, BMC Med Educ, 20 (2020) 285. doi:10.1186/ s12909-020-02208-z. - 7. VALLERAND RJ, FORTIER MS, GUAY F, J Pers Soc Psychol, 72/5 (1997) 1161. - 8. RYAN RM, DECI EL, Promoting self-determined school engagement: Motivation, learning, and well-being. In: WENTZEL KR, WIGFIELD A. (Eds): Handbook of motivation at school (New York City, Routledge, 2009). - 9. GAO Z, HANNON JC, NEWTON M, HUANG C, Res Q Exerc Sport, 82/3 (2011) 536. - 10. Middleton J, Jansen A, Goldin G, The complexities of mathematical engagement: Motivation, affect, and social interactions. In: CAI J. (Ed): Compendium for Research in Mathematics Education (NCTM, Reston, VA, 2017). - 11. ADA EN, ÇETINKALP ZK, ALTIPARMAK M, AŞÇI F, Asian J Educ Train, 4/2 (2018) 114. - 12. GREGORY GH, CHAPMAN livering their PE contents in time of the COVID-19 pandemic uncertainty. Pereira et al. $(2021)^{22}$ stated that a self-determined climate would lead to positive impact and engagement on the students' autonomous motivation in Physical Education. Therefore, the fostering of positive motivational climate through adaptive educational resources and alternative teaching approaches and methods would support and motivate the trainee teachers, educators and students in the teaching and learning of $\mathrm{PE}$ during this challenging time.

\section{Acknowledgements}

The authors declare no conflict of interest. The study is not supported by any funding. The authors like to express their appreciation to all participants who have participated in the study.
C. Creating a climate for learning. In: GAYLE HG, CHAPMAN C (Eds): Differentiated Instructional Strategies: One Size Doesn't Fit All (Thousand Oak, Corwin, 2007). - 13. YANTI MT, KUNTARTO E, KURNIAWAN AR, J Pendidik Dasar, 5/1 (2020) 61. doi:10.25078/aw.v5i1.1306. - 14. GRANERO-GALLEGOS A, BAENA-EXTREMERA A, GOMEZLOPEZ M, ABRALDES JA, Procedia Soc Behav Sci, 132 (2014) 364. 15. BAENA-EXTREMERA A, GRANERO-GALLEGOS A, PEREZQUERO FJ, BRACHO-AMADOR C, SANCHEZ-FUENTES JA, S Afr J Res Sport Phys Educ Recreation, 35/2 (2013) 1. - 16. GRÅSTÉN A, WATT A, J Sports Sci Med, 16/3 (2017) 318. — 17. KASIMOGLU M, Int J Res Educ Sci, 7/2 (2021) 412. doi:10.46328/ijres.2087. — 18. GUAY F, VALLERAND RJ, BLANCHARD C, Motiv Emot, 24/3 (2000) 175. doi: 10.1023/A:1005614228250. — 19. ØSTERLIE O, LØHRE A, HAUGAN G, Cogent Educ., 6/1 (2019) 1. doi:10.1080/2331186X.2019.1603613. — 20. PAPAIOANNOU A, Res Q Exerc Sport, 69/3 (1998) 267. doi: 10.1080/02701367.1998.10607693. - 21. SHILLING C, The body, class and social inequalities. In: EVANS J (Ed): Equality, education, and physical education (Routledge, London, 2017). — 22. PEREIRA P, MARINHO DA, SANTOS F, J Phys Educ Recreat Dance, 92/6 (2021) 42.

\section{N.S. Chin}

Institute of Teacher Education ITE Batu Lintang Campus, Jalan College, 93200 Kuching, Sarawak, Malaysia

e-mail: ngiensiong@gmail.com 


\section{SITUACIJSKA MOTIVACIJA UČITELJA PRIPRAVNIKA I MOTIVACIJSKA KLIMA ZA SATE TJELESNE I ZDRAVSTVENE KULTURE TIJEKOM PANDEMIJE COVID-19}

\section{S A Ž E T A K}

Ovo istraživanje nastojalo je ispitati situacijsku motivaciju učitelja pripravnika i motivacijsku klimu prema nastavi tjelesne i zdravstvene kulture (TZK) u osnovnim školama tijekom pandemije COVID-19. Sudionici su bili 160 učitelja pripravnika (115 muškaraca i 45 žena u dobi od 21 do 26 godina) iz dva kampusa Instituta za obrazovanje učitelja u Sarawaku, Malezija. Sudionicima je primijenjena Skala situacijske motivacije (SIMS) i Upitnik o motivacijskoj klimi u okviru nastave TZK (TIMCPEQ). Korištena je deskriptivna analiza, t-test neovisnih uzoraka, jednosmjerna ANOVA, dvosmjerna ANOVA i korelacija. T-test neovisnih uzoraka pokazao je da nema značajnih razlika za sve varijable u SIMS i TIMCPEQ prema spolu i dobnim skupinama. Jednosmjerna ANOVA korištena je za usporedbu učinka na nastavne metode u SIMS i TIMCPEQ. Postojala je značajna razlika u orijentaciji svladavanja gradiva koju je inicirao učitelj za tri nastavne metode. Post-hoc usporedbe pomoću Tukey HSD testa otkrile su da je srednja ocjena za online učenje značajno drugačija od mješovitih metoda učenja. Međutim, metoda učenja licem u lice nije se značajno razlikovala od online učenja i mješovitih metoda učenja. Nadalje, dvosmjerna ANOVA korištena je za ispitivanje učinka spola i dobnih skupina u SIMS i TIMCPEQ nije otkrila značajan učinak spola i dobnih skupina. Dodatno, nije bilo statistički značajne interakcije između spol × dobnih skupina za sve varijable u SIMS i TIMCPEQ. Rezultati su ukazali na statistički značajan pozitivan odnos između varijabli u SIMS i TIMCPEQ u rasponu od vrlo slabe do vrlo jake. Podatci ukazuju na nužnost poticanja pozitivne motivacijske klime, alternativne pristupe i metode poučavanja koji bi podržali i motivirali pripravnike, nastavnike i studente u podučavanju i učenju ovom izazovnom vremenu. 
